\title{
Educating for Ubuntu/Botho: Lessons from Basotho Indigenous Education
}

\author{
Moeketsi Letseka \\ Department of Educational Foundations, College of Education, \\ University of South Africa, Pretoria, South Africa \\ Email: letsem@unisa.ac.za
}

Received December $8^{\text {th }}$, 2012; revised January $10^{\text {th }}$, 2013; accepted January $24^{\text {th }}, 2013$

\begin{abstract}
Copyright (@) 2013 Moeketsi Letseka. This is an open access article distributed under the Creative Commons Attribution License, which permits unrestricted use, distribution, and reproduction in any medium, provided the original work is properly cited.
\end{abstract}

\begin{abstract}
This article reflects on shocking and horrifying incidents of moral indiscretion that have become commonplace in South Africa. The aim is to understand why human beings would carry out such shocking and horrific acts on fellow human beings. The article draws on Dismas Masolo's book Self and Community in a Changing World to unpack the notion of personhood. It draws lessens on Basotho indigenous education. The choice of Basotho indigenous education is premised on the assumption that it is the author's own native knowledge with which he is most familiar, and about which he can write uninhibitedly.
\end{abstract}

Keywords: Ubuntu/Botho; Personhood; Humanness; Basotho Indigenous Education; Morality; Moral Indiscretion

\section{Introduction}

On a daily basis homes, schools, work places and public spaces are bombarded by reports from the public media-the radio, television and print media on violent crime, murder, rape, assault, police brutality and similar moral indiscretions. A morally discerning person [however we define such a person] will be distressed upon listening to accounts of such moral indiscretion on the radio, watching their images on television or reading newspaper reports on them. This is because such reports raise serious questions about what it means to be moral, and how ought we to treat others. The title of ethicist Neil Levy's book What Makes us Moral? is most pertinent to the issues I am grappling with in this article. Levy (2004: p. 41) acknowledges that defining morality is no easy task. However, it is his contention that a moral system must be devoted, largely if not wholly, to a concern for the welfare of other people. Thus for Levy (2004: p. 44), a morality must systematize norms of justice and fairness and prescribe equal treatment for everyone. In this article I explore ways in which ubuntu/botho, understood as morality (Metz, 2007), humaneness (Mokgoro, 1998), and personhood (Letseka, 2000) can be taught with a view to "creating citizens"1 that are initiated in ubuntu/botho dispositions. I imagine such citizens to be inclined to treating others with justice and fairness at all times. In a recent article in The Chronicle of Higher Education Barry Schwartz and Kenneth Sharpe (2012)

\footnotetext{
${ }^{1}$ I borrow the idea of "creating citizens” from Eamonn Callan's (1997) book, Creating Citizens: Political Education and Liberal Democracy. Callan (1997: p. 3) advocates a political culture in which there is an active commitment to the good of the polity, confidence and competence in judgements regarding how that good should be advanced, and a respect for fellow citizens as well as a sense of common fate with them that goes beyond the tribalisms of ethnicity and religion and is yet alive to the significance these will have in many people's lives.
}

argue that as important as it is to teach students how to think critically and analytically, another fundamental that is largely neglected is the development of the intellectual virtues that students need to be good citizens. For Schwartz and Sharpe (2012), such virtues would entail the love of truth, honesty, courage, fairness, and wisdom. I shall argue that Basotho indigenous education sought to instruct the young people on makhabane (virtues) such as hard work, respect for persons, humility, perseverance, service to the nation, and patriotism. What is missing from the above-mentioned accounts of moral indiscretion is the notion of respect for persons and acknowledgement of the principles of the "golden rule".

The notion of ubuntu/botho has been widely theorized (Letseka, 2012, 2000; Metz, 2011, 2007; Bessler, 2008; Ramose, 2006, 2002, 1999; Broodryk, 2002; Sindane, 1994; Mokgoro, 1998; Shutte, 1994). On the one hand Ramose (2006) contends that $u$ buntu/botho represents the epistemological paradigm that informs the cultural practices, including the law, of Bantuspeaking peoples. While Broodryk (2002) conceives of ubuntu/ botho as a comprehensive ancient African worldview based on the values of humanness, caring, sharing, respect, compassion and associated values, ensuring a happy and qualitative human community life in a spirit of family. On the other hand Enslin and Horsthemke (2004) express doubts about the viability of ubuntu/botho as a model for citizenship education in African democracies, while Marx (2002) casts ubuntu/botho as an invented tradition whose task is to minimize historical chasms and fractures. Others have either offered a defense of ubuntul botho (Letseka, 2012), or argued a case for ubuntu/botho as a moral theory (Metz \& Gaie, 2010; Metz, 2007; Teffo, 1994), and as a public policy (Nkondo, 2007).

What I attempt to do in this article, which is a contribution to the debate in philosophy of education and African philosophy 
in South Africa, as well as a sequel to my previous contribution to this debate ${ }^{2}$, is to explore ways in which young people in schools and communities in South Africa can be initiated into ubuntu/botho moral dispositions. I shall draw on Masolo's (2010, 2004, 2003) articulation of the notion of personhood to argue that educating for ubuntu/botho should entail equipping young people with the kinds of attributes and dispositions that enable them to live lives that are anchored in communal understandings of personhood and humaneness. It is my contention that educating the young people for ubuntu/botho is sine qua non to addressing the social and cultural challenges of contemporary South Africa, which continues to be marked by the absence of a shared moral discourse (Morrow, 2007) and intolerance (Gibson \& Gouws, 2005).

The article is structured around five sections. First, I sketch media reports on a number of moral indiscretions that shock and horrify. My aim is to reflect on why human beings would do such shocking and horrifying deeds to fellow human beings. Second, I explore ways in which the notion of ubuntu/botho might respond to the above-mentioned incidents of moral indiscretion. Third, I tease out conceptions of personhood drawing on the work of Masolo (2010, 2004). Fourth, I sketch Basotho "indigenous education" (Matšela, 1990, 1979) and draw lessons from it that can be learned for framing a conception of education for ubuntu/botho in contemporary South Africa. Masolo (2010: p. 21) argues that the term "indigenous" defines the origin of an item or person in relation to how their belonging to a place is to be temporally characterized, especially in comparison to other contenders in claiming belonging. One might ask: but why Basotho indigenous education? If I could, I would happily write about Zulu indigenous education or Xhosa indigenous education, or any other ethnic group's indigenous education for that matter. But I cannot. Like Kwasi Wiredu and Kwame Gyekye who have written extensively on Akan notions of morality and personhood, which is their own native knowledge and one about which they can write uninhibitedly, I am a Mosotho who was brought up in a traditional Sotho homestead in rural Lesotho. Realistically therefore, I can offer my readers an account of Basotho indigenous education which is likewise my own native knowledge with which I am most familiar, and about which I can write uninhibitedly. I take education to be more than just schooling, but to also encompass transmission of the culture(s) of society from one generation to the other (Adeyinka, 1993). But I am also persuaded that educating the young people should entail exposing them to other cultures besides the cultures in which they are born and bred. In the final section I offer some concluding remarks.

\section{Incidents of Moral Indiscretion}

A young mother is gunned down by two masked men on a motorcycle after dropping her five-year-old son at a crèche (Hosken, 2011); a man charged with the brutal murder of a tenyear old girl for her body parts to be used for muti is sentenced to life imprisonment (Dlamini, 2011); a mob sets alight and kills an elderly couple whom it accused of practicing witchcraft (Mkamba, 2012); four men are jailed for eighteen years each by a Cape Town Court for stabbing and stoning a 19-year girl to death for being a lesbian (Pretoria News, 2012). The abovementioned incidents are shocking and horrifying. They cause a

${ }^{2}$ See Moeketsi Letseka (2012) “In Defence of Ubuntu”, Studies in Philosophy and Education, 31 (1), 47-60. morally discerning person to pause and wonder what happens to human beings when they carry out such shocking and horrifying acts on fellow human beings, and to speculate on how society ought to respond to such incidents.

In a newspaper commentary titled "Socializing our boys to be better men” Rhema Church senior Pastor Ray McCauley (2012) notes that "three acts of rape in our country in the past two weeks call into question the type of society we have become. More importantly, they call for urgent action and community mobilization against these ever-increasing inhumane and barbaric acts against often defenseless women and children”. McCauley (2012) recounts the gang rape of a 17-yearold mentally ill girl in Soweto; the rape by a girl and a woman, of a 17-year-old mentally ill boy, again in Soweto, and a 15year-old boy who raped, bit and gouged the eyes of an 8-yearold girl in KwaZulu-Natal. McCauley suggests that "we need to deal with this shame among us not necessarily as a response to the negative image created about us internationally, but because fundamentally we reject any form of violence against women, children and the vulnerable among us". He makes three important observations: first, the incidents cited show that a subculture of rape and violence is taking root (if it hasn't already) among our boys. Second, the coercive sexual behavior against the vulnerable (in this case the mentally disturbed and children) continues. And third, though in South Africa we seldom talk about female-on-male rape, the rape of boys by women is beginning to surface and could be happening more often than society cares to admit. McCauley contends that the stereotypical behaviors of boys are not obtained by birth. Rather, they are acquired as the boys keep growing. He is concerned that this raises the issue of the kind of values that fathers and men in general impart to their boys, the kind of role models the boys can emulate, and the role schools, through a deliberate curriculum ought to play. For McCauley, gender equality and respect for the opposite sex should be systematically woven into the school curriculum if we are to socialize our boys to be better men. I couldn't agree more. As I will show in the pen-ultimate section of this article Masolo (2010) rejects cultures that teach children that males are more valuable than females. Personally I reject the gendering of roles which privileges one gender over the other.

What I am trying to understand in this article is ways in which individuals ought to treat one another. For instance, what should frame the ways in which we ought to treat one another, and in turn how ought others to treat us were they to find themselves in circumstance that put their conduct on the spotlight? The reader will notice that I use the notion of "ought" to make a case for moral conduct. The reason for this, Scottish philosopher Alasdair MacIntyre (1959: p. 457) explains, is that the notion of "ought" is only explicable in terms of the notion of a consensus of interest. To say that we ought to do something is to affirm that there is a commonly accepted rule; and the existence of such a rule presupposes a consensus of opinion as to where our common interests lie. Thus the concept of "ought" is logically dependent on the concept of a common interest and can only be explained in terms of it. Greenspan (2007: p. 172) concurs. She argues that "when we say that someone morally ought not to harm others, perhaps all we are saying is that he has a certain kind of reason not to, one that wins out against any opposing reasons such as those touting benefits to him of ignoring others' concerns". Thus "the good" or "what ought to be" does not reside in some abstracted, conceptual "moral or- 
der" with its own existence "out there" but occurs in specific instances in which persons discover what is right to do and then do it (Crysdale, 1987: p. 105).

Australian moral philosopher Peter Singer provides useful insights here. In his two books, Writings on an Ethical Life and How are we to live? Ethics in an Age of Self-interest, Singer (2002, 1997) expounds on what ought to shape our moral attitudes and humane treatment of others. He picks out four critical sayings on the "moral law" or the "golden rule", which he suggests ought to guide the way we treat others at all times:

"Love thy neighbor as yourself" (Jesus).

"What is hateful to you do not do to your neighbor" (Rabbi Hillel).

"What you do not want done to yourself, do not do to others" (Confucius).

"Let no man do to another that which would be repugnant to himself (The Mahabharata).

What seems to be presumed in these sayings is that individuals are capable of reasoning and placing themselves in the shoes of those they are most likely to hurt by their actions; they are capable of judging if their intended actions have the potential to cause pain that even they would not endure, and that they take responsibility for their own actions (Wiredu, 1992). It is Singer's (1997: p. 201) contention that ethics is everywhere in our daily lives. It lies behind many of our choices, whether personal or political, or bridging the division between the two. These views resonate with Wiredu's (1992: p. 193) position that morality is not only universal, but essential to all human cultures. For Wiredu, morality is observance of rules for the harmonious adjustment of the interests of the individual to those of others in society. He contends that the imperative for morality should be: "in all inter-personal situations put yourself in the skin of the other and see if you can contemplate the consequences of your proposed action with equanimity". I fully support this view.

\section{Ubuntu/Botho's Response to Incidents of Moral Indiscretion}

The question, how should ubuntu/botho respond to premeditated murder, muti killings, burning of the elderly people on suspicion of witchcraft, homophobic killings, and other such moral indiscretions, places ubuntu/botho morality on the spotlight. The issues raised by the above question are pertinent to ubuntu/botho given that ubuntu/botho is a normative concept. Just to recap on how the normative aspects of ubuntu/botho have been theorized, Broodryk (2002: p. 13) describes it as "a comprehensive ancient African worldview based on the values of intense humanness, caring, sharing, respect, compassion and associated values". Ramose (2006: p. 366) contends that $u b$ untu/botho represents the epistemological paradigm that informs the cultural practices, including the law, of the Bantuspeaking peoples. In another publication Ramose (2002) locates ubuntu/botho within the realm of the African existential world and African conceptions of knowledge. He describes $u b$ untu/botho as the wellspring flowing with African ontology and epistemology. Botho features prominently in debates on Sesotho literary works where it is regarded as "the full expression of one's humanity” (Shanafelt, 1988: p. 51).

Viewed from within traditional African thought ubuntul botho can be said to articulate our communal inter-connectedness, our common humanity, our interdependence and our common membership to a community. Most importantly, $u b$ untu/botho raises very strong normative issues. As Metz (2007: p. 323) observes, ubuntu/botho grounds a normative ethical theory of right action, analytically setting aside ubuntu/botho as a comprehensive worldview or a description of a way of life as a whole. In another publication Metz and Gaie (2010: p. 285) contend that this grounding is premised on the assumption that in African moral theory, actions are right roughly insofar as they are a matter of living harmoniously with others or honoring communal relationships. Masolo (2010: p. 249) echoes similar sentiments in his observation that the sense of belonging, or the realization and acceptance that the self is located in the midst of others, becomes the basis of his or her moral outlook within the context of a common set of values. Within this mode of thought, no person is considered to be a self-sufficient entity in and for him or herself. Rather, the existence of others is an essential part of the very structure of the self, from which emanates the communitarian exigency. For Masolo, the community is thus crucially differentiated from the "masses". It is not just a collectivity. Rather, it is built through deeds in which are inscribed a person's contribution to the building of the community.

It can be inferred from the above analysis that ubuntu/botho morality would eschew the type of moral indiscretions that are the subject of this article. In sub-Saharan African moral thought the expression: "Motho ke motho ka batho babang" (Sotho languages) or "Umuntu ngumuntu ngabantu" (Nguni languages), indicates some descriptive claims about the dependence of a human being, particularly a child, on other human beings for her survival or for the course her life takes (Metz \& Gaie, 2010: p. 275). For Louw (2006: p. 161), umuntu ngumuntu ngabantu articulates a basic respect for compassion. Thus umuntu ngumuntu ngabantu is both a factual description and a rule of conduct or social ethic. It not only describes human beings as "being-with-others", but it also prescribes how human beings should relate to others: that is, what beingwith-others should be all about. French philosopher Jean-Paul Sartre cogently articulates the notion of being-with-others in his book Being and Nothingness. Sartre (2003: p. 434) argues that we discover ourselves not in conflict with the other but in community with him. For Sartre (2003: p. 435), the "we" includes a plurality of subjectives which recognize one another as subjectivities. The "we" is a certain particular experience which is produced in special cases on the foundation of being-forothers in general. The being-for-others precedes and founds the being-with-others (Sartre, 2003: p. 436). Louw (2006: p. 167) echoes similar sentiment to Sartre's above in his observation that $u$ buntu dictates that if we are to be human, we need to recognize the genuine otherness of our fellow citizens; acknowledge the diversity of languages, histories, values, and customs, all of which constitute the South African society. Indeed for Louw (2006: p. 169), respecting the historicity of the other means respecting his/her dynamic nature or process nature. An " ubuntu perception of the other is never fixed or rigidly closed, but adjustable and open-ended. It allows the other to be, to become”.

Adding to the above voices Nussbaum (2003: p. 21) contends that ubuntu/botho is the capacity in African culture to express compassion, reciprocity, dignity, harmony, and humanity. She argues that ubuntu sees community rather than selfdetermination as the essential aspect of personhood. People are distinctive beings, able to recognize and acknowledge each 
other through mutual encounters and cultural integration (Nussbaum, 2003: p. 22). Thus through ubuntu/botho, "our deepest moral obligation is to become more fully human” (Shutte, 2001). My own view is that it would be uncharacteristic for an individual who is sufficiently immersed in ubuntu/botho to contemplate rape or murder because anyone who rapes or murders becomes, as it were, depersonalized. Elsewhere I have argued that it would be illogical for anyone with ubuntu/botho to demonstrate concern for others and at the same time have the inclination to rape, because rape is an affront to, and is inconsistent with ubuntu/botho moral norms and values (Letseka, 2000: p. 186). The reason for this is that ubuntu/botho is a normative concept that prescribes desirable and accepted forms of human conduct in a particular community of people. We are batho or abantu (persons) because we live lives that are consistent with communally accepted and desirable ethical standards (Letseka, 2000: p. 186). While ubuntu/botho ethic entails some elements of the "golden rule", it extends beyond just requiring one to treat others as one would like to be treated in that it encompasses a multiplicity of normative values such as caring, sharing, respect for others, compassion, altruism, kindness, generosity, benevolence, and courtesy. In the next section I tease out conceptions of personhood with a view to showing how personhood plays itself out with respect to morality.

\section{Conceptions of Personhood}

The notion of ubuntu/botho, understood as personhood and morality is at the heart of my argument in this article. It is my view that personhood is linked to humane conduct, and that humane conduct is synonymous with good moral conduct. Concomitantly, good moral conduct implies treating others at all times with fairness, dignity and justice. Good moral conduct is predicated on individuals reasoning about their intended actions and making rational choices to act in a particular way, and to avoid acting in other ways that might be deemed to be an affront to good moral conduct. This view of morality is attributed to German philosopher Immanuel Kant, who maintained that morality is encapsulated in a rule which he called the categorical imperative. Kant argued that the categorical imperative is a command or duty to act according to an objective principle of reason. Such a command requires that we should act in such a way that we can also will that our maxim should become a universal law (Kant, 2005: p. 22). For Kant (2005: p. 29), “to justify the categorical imperative we have to show that a fully rational agent would necessarily act in a certain way". Bandura (1999: p. 193) cautions though that the regulation of humane conduct involves much more than moral reasoning. He argues that a complete theory of moral agency must link moral knowledge and reasoning to moral action. Bandura draws on social cognitive theory to argue that moral reasoning is translated into actions through self-regulatory mechanisms rooted in moral standards and self-sanctions by which moral agency is exercised. This way a proactive form of morality is expressed in the power to behave humanely (Bandura, 1999: p. 194). In a humane society, all human beings have a right to pursue happiness. In turn, that right goes beyond one's right to the duty to respect this same right in others, not to hinder it, perhaps even to promote it. By implication then, in a humane society, there has to be respect for variety and difference.

What is Masolo's $(2010,2004)$ view on personhood? Masolo (2010: p. 13) uses the concept of juok, in the Luo language of
Eastern Africa to delineate the notion of personhood. He writes that in the social and moral senses, juok means an anti-social attitude and character. Behavior is branded as juok if it is intentionally aimed at harming others or if it is intentionally weird and out of line with expectations of reasonableness toward other people and/or things (Masolo, 2010: p. 199). Thus the concept (of juok) draws attention to the imagination and practice of right conduct. It is the moral guiding principle in the interactive inter-subjectivity of everyday life. Rooted in a communalistic ethic, the concept of juok underlines a strategy for containing socially destructive conduct by reminding people of the deviant and stigmatizing nature of antisocial behavior. In its denotation of character, juok is a descriptive term used to order the everyday reality of social and moral behavior of individuals and groups (Masolo, 2010: p. 185). For Masolo (2010: p. 139) then, because personhood is socially generated, interaction or inter-subjective penetration, not aggregation, is the formative foundation of human nature and the conduit through which humans develop their sense and basis of moral and cognitive values. He elaborates: "By means of communicative interaction we become more than just human beings: we become persons" (Masolo, 2010: p. 142). This view of personhood resonates with the view advocated by Menkiti (1984: p. 171). The latter advocates a conception of personhood found in African traditional thought which defines a person by reference to the environing community. He writes: "morality demands a point of view best described as one of beingness-with-others" (Menkiti, 2004: p. 324). In this regard community plays a vital role both as catalyst and as prescriber of norms in the stated journey of the individual towards personhood.

Masolo's (2004: p. 27) view on morality therefore is that "because morality is a relational category, the moral potentialities we bear enable us to imaginatively project ourselves into the situation of others, making it possible for us to make judgments about others' cases as if they were our own”. He notes that "conflicts between communal demands and individual choices clearly raise issues of the location of moral reason that guides the idea of the moral good" (Masolo, 2003: p. 31). Is the individual then as autonomous as some schools of liberalism demand? Masolo (2010: p. 222) is explicit in chapter 6 of his book The Self and Community in a Changing World that communitarianism "is the antithesis of individualism, but its manifestations in intellectual traditions around the world reveal important regional modifications". One might ask then: should the community be the sole source of moral reason? Citing contemporary Western communitarians such as Alasdair MacIntyre, Michael Sandel, Michael Walzer and Charles Taylor, Masolo (2010: p. 226) notes that "while not denying the autonomy of the individual, they emphasize the significance of her participation in as well as dependence on the community for her sense of self, for her freedom, and for her moral development and agency. According to this view, individuals are constituted by the institutions and practices of which they are part and their rights and obligations derive from those same institutions". For Masolo (2010: p. 241), knowledge of communitarian values is passed on to individuals at crucial points in their growth and development from childhood to adulthood. This is done both systematically through well-defined procedures and randomly in the course of everyday life where people learn from the examples of others, from various modes of speech. Thus in African modes of thought, the concept of personhood is closely related to the defining capacities of humans. In this sense, being 
a person is attained through an educational process that intensifies at every stage in a person's growth and development (Masolo, 2010: p. 241).

The key issue I am grappling with in this article is how one ought to behave in order to live a life that is shaped by $u b$ untu/botho morality? In a sense, what sort of personhood is required to enable one to live a life that is imbued with $u b$ untu/botho morality? For Masolo (2010: p. 174), "a social constructivist theory of personhood claims that ideas about the nature of persons are formed in the course of society's value choices and practices that cohere with their other views and interpretations of the general nature of the universe". According to this logic personhood is constituted by the theories, practices, and institutions that a society may deem meaningful to its peculiar experiences. The issue at stake here is whether the location of morality should be at community level or at the level of the individual? The work of Canadian philosopher Charles Taylor is very instructive. Taylor (1991: p. 161) argues that often the choice is not simply between a close, family-like community and a modern, impersonal society. Instead it is possible for someone to have communitarian or holist ontology and to value liberalism's individual rights (Abbey \& Taylor, 1996: p. 3). For Wiredu (1996: p. 72), the distinction between communalism and individualism is one of degree only. A considerable value may be attached to communality in individualistic societies, just as individuality is not necessarily trivialized within communalism. The two orientations can co-exist in different sectors of the same society. I now turn to Basotho indigenous education.

\section{Educating for Ubuntu/Botho through Basotho Indigenous Education}

The notion of African traditional education or "indigenous education" has been well documented (Kingsley, 2010; Marah, 2006; Mapesela, 2004; Maharasoa \& Maharasoa, 2004; Ntsihlele, 2003; Adeyemi \& Adeyinka, 2003, 2002; Matšela, 1990, 1979). In this section I briefly explore the notion of Basotho “indigenous education” as delineated by Matšela (1990, 1979). As I mentioned in the introduction I have chosen Basotho indigenous education because it is my own native knowledge, and one with which I am not only familiar, but one about which I can also expound uninhibitedly. I am persuaded that useful lessons can be drawn from the way Basotho "indigenous education" was used to create citizens with the kind of personhood that was deemed necessary for "good" human conduct among Basotho communities. Again as I indicated in the introduction I take education to be more than just schooling, but to refer to a process of transmitting the culture of society from one generation to the other (Adeyinka, 1993). Adeyinka (2000: pp. 19-20) defines education as the process of transmitting the culture of a society from one generation to the other, the process by which the adult members of a society bring up the young ones. What I attempt to do in this section is to reflect on education and morality in Africa (Adeyinka \& Ndwapi, 2002). Adeyemi and Adeyinka (2002: p. 223) note that before the arrival of the missionaries and the introduction of Western civilization into Africa "education on the continent was purely indigenous", that is, it was "generally known as African traditional education or "indigenous education” of various communities" (Adeyemi \& Adeyinka, 2003: p. 425).

Indigenous education in Africa was intimately integrated with the social, cultural, artistic, religious, and recreational life of the ethnic group (Marah, 2006: p. 15). Masolo (2010: p. 251) endorses this view. In what he terms "social education" he argues that in most traditional African societies individuals were taught about the structure of their social environment and their place in that structure. This knowledge unveiled to them not only how they related to the whole but also how they were expected to behave toward everyone within it, social expectations that were determined by how the initiate was related to each member. Thus the education that the African youth received fitted the group and the expected social roles in society were learned by adulthood. The “African youth's ethnic group and community were held by rules and regulations, values and social sanctions, approval, rewards and punishments, etc., into which he was inducted" (Marah, 2006: p. 17). It might be argued that African indigenous education promoted gendered roles in society. Traditional Africanists might not deny that in traditional African societies and their cultures there were specific roles for males and specific roles for females.

Can we pass judgment on how these societies were ordered? What yardstick would we be using? How fair will such a yardstick be? Will it enable us to understand such societies within their historical and cultural context or as gender relations are perceived in our times? Nzegwu (1998: p. 602) sensitizes us to the importance of historicity. She argues that historicizing interpretations involves "using appropriate yardsticks so that the time frames are not illicitly collapsed and conceptual frames of cultures are not illicitly switched”. However, I should mention that as a modern cosmopolitan male I would be appalled by the gendering of roles that privileges one gender over the other. As Masolo (2010: pp. 52-53) points out, if our cultures teach us from childhood that males are more valuable than females, we are likely to grow up believing that such a statement of gender inequality is a true description of the social order, and if we are male, it may lead us to believe that we are justified in treating women as unequals in the family and in the workplace. Masolo (2010: p. 251) is unequivocal that a person is morally good when he strictly observes the rules that separate gendered spaces in society and where such separation is made out of respect rather than to discriminate. Reminiscing about his experiences of gender relations in his hometown of Mombasa, Kenya, Masolo (2010: p. 132) recalls that in the good but longgone old days, everyone knew that at the taxi stop mothers, people of the female gender, children, and the elderly boarded and alighted first and that no one pushed anyone else. These mores were so well known that no one needed to be reminded of them. Masolo informs us that in Swahili this is known as ustaarabu—social civility.

I am persuaded that Basotho indigenous education also strove for the kind of social civility to which Masolo refers above. But I want to take the argument even further by suggesting that it was also functional and participatory. Young people learned through initiation ceremonies, work, play, oral literature, ditśomo-Sotho folk tales or legends, and dilothoriddles (Futhwa, 2011). I will say more on ditśomo in a short while. For now I want to briefly commend on the non-formal nature of Basotho indigenous education. Matšela (1979: p. 188) notes that non-formal education comprises a variety of forms of training and education taking place anywhere and anytime, other than in initiation academies, and specialized professional training. He argues that the education of a Mosotho child entailed cultural values, philosophy, personal and family respon- 
sibilities and duties to the clan and the people (Matšela, 1979: p. 159), or what Masolo (2010: p. 173) calls "a mix of education and trial-and-error experiences”. He contends that moral education and the acquisition of the values that sustain the social order are part of initiation rituals in most African societies. These rituals, which are an important aspect of the rites of passage, "create" a person out of the untamed and unmolded body of a child (Masolo, 2010: p. 242).

My own initiation into family responsibilities began as a herd boy tasked to look after my father's cattle. Herding was a responsibility every Mosotho boy was expected to carry out with distinction. A herd boy who excelled in his tasks and responsibilities was known as a Motjodi-the Euplectes progne, or a long-tailed widowbird, implying one who leads. Mapesela (2004: p. 322) argues that Basotho indigenous education inculcated good ethics, morals and values such as humaneness ( $u b$ untu), neighborliness, responsibility, and respect for self and others. It is his view that Basotho indigenous education "can still be used to encourage people to become better members of society, as well as to help curb certain social problems ... a lack of neighborliness (leading to heartlessness, theft, killing and rape), a lack of ubuntu (resulting in an uncaring and unpatriotic society); as well as a lack of good ethics (leading to an irresponsible, lazy and poor society)”. In a way, Basotho indigenous education could be a useful response to Pastor Ray McCauley's concerns above on the need to socialize boys to be better men, and I should add, girls to be better women. Thus indigenous education is a process of cultural transmission and renewal whereby the adult members of society carefully guide the development of infants and young children, initiating them into the culture of society (Adeyemi \& Adeyinka, 2002: p. 224).

African indigenous education was also communal. Adeyinka and Ndwapi (2002: p. 18) argue that given that most communities in pre-colonial Africa were agrarian, all citizens would engage in the clearing of individual member's farm-bush, and would work together during planting and harvesting season. Elsewhere I have remarked on the letsema-cooperative community farming among the Basotho where I note that "four or more families would come together and agree on a duty roster that would allow them to cultivate each of their fields on agreed days to make them ready for the planting season” (Letseka, 2000: p. 183). But letsema was not just a cooperative community effort. On the contrary, through letsema members of the community recognized that it would be difficult and slow for individual families to complete the cultivation of their fields on time if each family was to go it alone (Letseka, 2000: p. 184). As Adeyinka and Ndwapi (2002: p. 18) point out, part of the purpose of African traditional education was the development in children of a communal spirit, by which each individual saw himself/herself as part of a bigger unit, working and living together for the common good. It can therefore be reasonably inferred that African traditional education inculcated in young people feelings of belonging and interdependence between all the members of the community, or what Masolo (2010: p. 240) calls "a life of cohesion, or positive integration with others".

Let me now briefly commend on two key aspects of Basotho "indigenous education" that I regard as essential to the development of personhood. These are lebollo and ditśomo. First, lebollo or initiation school. Matšela (1990: pp. 53-56) contends that lebollo aimed to equip youngsters with competencies that are necessary for adulthood. These included bohloeki (purity), which is advocacy for cleanliness both in its literal form as it relates to hygienic living, and in its metaphorical form as it relates to mind and soul or inner self. Lebollo sought to instill competencies such as thuto-kelello (cognitive engagement). that is, the ability to think strategically and at the highest level. The initiates were initiated ${ }^{3}$ in a problem-based education. They were presented with problems pertaining to real life situations in society and challenged to develop long-term solutions. They were instructed on makhabane (virtues), which included industry or hard work, respect for persons, humility, perseverance, service to the nation, patriotism, leruo (wealth), makunutu a sechaba (national secrets or classified information), bonatla (warriorship), and boqapi le bokheleke (creativity and eloquence). With respect to leruo [wealth] Maharasoa and Maharasoa (2004: p. 111) observe that the Sesotho proverb: "mphemphe e ea lapisa, motho o khonoa ke sa hae" (begging begets poverty; an individual is better served by the sweat of his or her brow) was used to fuel the spirit of self-reliance and to discourage economic inertia. It thereforen seems reasonable to argue that among other things, the lebollo sought to instill those virtues that are regarded as worthwhile and sustainable in traditional African thought.

Second, ditśomo-folk tales that are orally passed down from one generation to the next and become part of the community's tradition. Coplan (1993: p. 92) observes that like auriterary metaphors, ditśomo are intended to startle untamed meanings from their burrows. They are full of surprises and attacks ranging from the uncanny to the fantastical, with mythical creatures, wild animals, and even wilder humans pursuing improbable stratagems. But at the heart of ditśomo are home truths about the nature of humanity and society, which is why ditśomo are so central to Basotho social philosophy. One of the most popular tśomo among the Basotho is the tale of Khodumodumo and moshanyana' Sankatana. Khodumodumo is a monster that embodies the white South African state, which envelops the black multitudes into bondage. Sankatana represents the young liberator. Khodumodumo appears and consumes the entire Basotho nation in its wake except one pregnant woman who escapes by camouflaging herself by smearing her body with ashes and cow dung instead of ochre. Khodumodumo mistakes her for a soilencrusted stone and spares her. As it departs Khodumodumo gets stuck at the mountain pass and cannot cross to the other side. Meanwhile the woman gives birth to a boy who miraculously grows into a young man, fully accoutered with a blanket, a spear and shield, and who identifies himself as Sankatana (the ragged-one) (Coplan, 1992). Sankatana battles the monster with his spear, kills it and frees the captives. Coplan (1992: p. 93) argues that the story of Khodumodumo (culture villain) and Sankatana (culture hero) plays around with a series of culturally sentient metaphoric tropes, bringing them into metonymic relationship and creating a dialogue between social ideology and practice. Centrally, it is the tale of a hero who defeats the villain and frees the people from political and cultural bondage.

By way of closing let me hasten to mention that while I support the principles of Basotho indigenous education as expounded above, especially its emphasis on grounding the knowledge of young people in community values, I also recognize the importance of exposing the young people to the wider world

${ }^{3}$ The notion of "Education as initiation" was given prominence by British philosopher of education Richard Stanley Peters in his inaugural lecture delivered at the Institute of Education, University of London, 9 December 1963. 
and to different cultures, or what is commonly known as cosmopolitanism (Gitlin, 2006; Nussbaum, 2002). I cognizant that nations are not natural, organic, objective, or anything of that sort but are the inventions-“constructions"- of intellectuals and the stories that they tell about history and culture (Gitlin, 2006: pp. 130-131). As Nussbaum (2002: p. 9) cogently puts it, to be a citizen of the world one does not need to give up local identifications, which can frequently be a source of great richness in life. Instead, we should think of ourselves not as devoid of local affiliation. Nussbaum (2002: p. 8) makes a case for education for world citizenship on three grounds. First, the study of humanity as it is realized in the whole world is valuable for self-knowledge: we see ourselves more clearly when we see our ways in relation to those of other reasonable people. Second, only by making our fundamental allegiance to the world community of justice and reason can we avoid the dangers of local allegiances and partisan loyalties. And third, cosmopolitan politics recognizes in people what is especially fundamental about them, most worthy of respect and acknowledgment: their aspirations to justice and goodness and their capacities for reasoning in this connection. If educating for ubuntu/botho was to focus only on local, African or indigenes, and preclude exposure to what the rest of the world has to offer, I would regard such an education as simplistic, parochial, antieducational and not worthwhile pursuing.

\section{Conclusion}

What I have attempted to do in this article is to highlight incidents of moral indiscretion and to warn against their implications for our taken-for-granted notions of good moral conduct. I described such incidents as shocking and horrifying to morally discerning individuals. I sketched the underlying assumptions of Basotho "indigenous education" with a view to reflecting on lessons that can be learnt from such an education in order to "create citizens" that are immersed in ubuntu/botho, understood as personhood, humaneness and morality. My view is that invoking the notion of Basotho indigenous education is neither nostalgic yearning for the long gone past, nor the movement to retreat to the "caves" and "bushes". Instead it is recognition that some of the values and ideas of indigenous African systems can add value to the way contemporary African cultures and politics are ordered. If we agree that ubuntulbotho is a cohesive moral value that grounds a normative ethical theory of right action as Teffo (1994) and Metz (2007) argue, then it follows logically that ubuntu/botho would eschew rape, assault, domestic abuse, murder, muti killings or homophobic killings because these would be incompatible with ubuntu/botho morality. I argued that educating the young people for ubuntu/botho through Basotho indigenous education has the potential to contribute towards the ideal of creating citizens that are inclined to treating others with fairness, dignity and justice at all times. I showed that among the Basotho indigenous education was anchored in communal experiences such as letsema or cooperative community farming, the institution of lebollo, the telling of ditśomo, or folk tales, which are critical to Basotho social philosophy.

\section{REFERENCES}

Abbey, R., \& Taylor, C. (1996). Communitarianism, Taylor-made: An interview with Charles Taylor. Australian Quarterly, 68, 1-10. doi:10.2307/20634713
Adeyemi, M. B., \& Adeyinka, A. A. (2003). The principles and content of African traditional education. Educational Philosophy and Theory, 35, 425-440. doi:10.1111/1469-5812.00039

Adeyemi, M. B., \& Adeyinka, A. A. (2002). Some key issues in African traditional education. McGill Journal of Education, 37, 223-240.

Adeyinka, A. A., \& Ndwapi, G. (2002). Education and morality in Africa. Pastoral Care in Education: An International Journal of Personal, Social and Emotional Development, 20, 17-23. doi:10.1111/1468-0122.00225

Adeyinka, A. A. (2000). Basic concepts in education: the issues at stake. In H. J. Msango, E. C. Mumba, \& A. L. Sikwibele (Eds.), Selected topics in philosophy and education. Lusaka: University of Zambia Press.

Adeyinka, A. A. (1993). Crisis in Nigerian education: The issues at stake. Nigerian Journal of Educational Foundations, 4, 1-17.

Bandura, A. (1999). Moral disengagement in the perpetration of inhumanities. Personality and Social Psychology Review, 3, 193-209. doi:10.1207/s15327957pspr0303_3

Bessler, J. D. (2008). In the spirit of ubuntu: Enforcing the rights of orphans and vulnerable children affected by HIV/AIDS in South Africa. Hastings International and Comparative Law Review, 31, 33113.

Broodryk, J. (2002). Ubuntu: Life lessons from Africa. Pretoria: Ubuntu School of Philosophy.

Callan, E. (1997). Creating citizens: Political education and liberal democracy. Oxford: Clarendon Press.

Coplan, D. B. (1993). History is eaten whole: consuming tropes in Sesotho auriture. History and Theory, 32, 80-104. doi:10.2307/2505633

Crysdale, C. S. W. (1987). From “is” to “ought”: Kohlberg, Lonergan, and method in the human sciences. Laval Théologique et Philosophique, 43, 91-107.

Dlamini, P. (2011). Muti killer gets life. Sowetan, 29 November 2011.

Enslin, P., \& Horsthemke, K. (2004). Can ubuntu provide a model for citizenship education in African democracies? Comparative Education, 40, 545-558. doi:10.1080/0305006042000284538

Futhwa, F. (2011). Setho: Afrikan thought and belief system. Alberton: Nalane ka Fexekile Futhwa.

Gibson, J. L., \& Gouws, A. (2005). Overcoming intolerance in South Africa: Experiments in democratic persuasion. New York: Cambridge University Press.

Gitlin, T. (2006). The Intellectuals and the Flag. Columbia University Press: New York.

Greenspan, P. (2007). Practical reasons and moral ought. In R. ShaferLandau (Ed.), Oxford studies in metaethics (Volume II, pp. 171-194), Oxford: Oxford University Press.

Hosken, G. (2011). Riddle as young mom is gunned down by motorcyclists. The Star, 9 November 2011.

Kant, I. (2005). The moral law: Groundwork of the metaphysic of morals. Abington: Routledge Classics.

Kingsley, O. (2010). African traditional education: A viable alternative for peace building process in modern Africa. Journal of Alternative Perspectives in the Social Sciences, 2, 136-159.

Letseka, M. (2012). In defense of ubuntu. Studies in Philosophy and Education, 31, 47-60. doi:10.1007/s11217-011-9267-2

Letseka, M. (2000). African philosophy and educational discourse. In P. Higgs, N. C. G. Vakalisa, T. V. Mda, \& N. T. Assie-Lumumba (Eds.), African voices in education (pp. 179-193). Cape Town: Juta.

Levy, N. (2004). What makes us moral: Crossing the boundaries of biology. Oxford: Oneworld Publications.

Louw, D. J. (2006). The African concept of ubuntu and restorative justice. In D. Sullivan, \& L. Tifft (Eds.), Handbook of restorative justice: A global perspective. New York: Routledge.

MacIntyre, A. (1959). Hume on "is" and "ought". The Philosophical Review, 68, 451-568. doi:10.2307/2182491

McCauley, R. (2012). Socializing our boys to be better men. The Star, 7 May 2012.

Maharasoa, M. M. A., \& Maharasoa, M. B. (2004). Men’s initiation school as a form of higher education within the Basotho indigenous knowledge system. South African Journal of Higher Education, 18, 106-114.

Mapesela, M. L. E. (2004). The Basotho indigenous knowledge (IK): 


\section{LETSEKA}

Do we understand it well enough to employ it as a tool in Higher Education. South African Journal of Higher Education, 18, 316-326.

Marah, J. K. (2006). The virtues and challenges in traditional African education. Journal of Pan African Studies, 1, 15-24.

Masolo, D. A. (2010). Self and community in a changing world. Bloomington and Indianapolis: Indiana University Press.

Masolo, D. A. (2004). Reason and culture: Debating the foundations of morals in a pluralist world. Diogenes, 51, 19-31. doi:10.1177/0392192104044271

Masolo, D. A. (2003). Philosophy and indigenous knowledge: An African perspective. Africa Today, 50, 21-38. doi:10.1353/at.2004.0015

Matšela, Z. A. (1990). Bochaba ba Basotho. Mazenod: Mazenod Publishers.

Matšela, Z. A. (1979). The indigenous education of the Basotho and its implications for educational development in Lesotho. Unpublished Ed.D Thesis, Boston, MA: University of Massachusetts.

Marx, C. (2002). Ubu and ubuntu: On the dialectics of apartheid and nation building. Politikon, 29, 49-69. doi:10.1080/02589340220149434

Menkiti, I. A. (2004). On the normative conception of a person. In K. Wiredu (Ed.), A companion to African philosophy (pp. 324-331). Oxford: Blackwell Publishing.

Menkiti, I. A. (1984). Person and community in African traditional thought. In R. A. Wright (Ed.), African philosophy: An introduction (3rd ed., pp. 171-181). New York: University Press of America.

Metz, T. (2011). An African theory of dignity and a relational conception of poverty. In J. W. de Cruchy (Ed.), The humanist imperative in South Africa (pp. 233-242). Stellenbosch: Sun Press.

Metz, T. (2007). Towards an African moral theory. The Journal of Political Philosophy, 15, 321-341. doi:10.1111/j.1467-9760.2007.00280.x

Metz, T., \& Gaie, J. B. R. (2010). The African ethic of Ubuntu/Botho: Implications for research on morality. Journal of Moral Education, 39, 273-290. doi:10.1080/03057240.2010.497609

Mkamba, L. (2012). No bail for mob killing suspects. Pretoria News, 27 November.

Mokgoro, Y. (1998). Ubuntu and the law in South Africa. Buffalo Human Rights Law Review, 15, 1-6.

Morrow, W. (2007). Learning to teach in South Africa. Cape Town: HSRC Press.

Nkondo, G. M. (2007). Ubuntu as public policy in South Africa: A conceptual framework. International Journal of African Renaissance Studies, 2, 88-100.

Ntsihlele, F. M. (2003). Games, gestures and learning in Basotho children's play songs. Pretoria: University of South Africa (Unpublished).

Nussbaum, B. (2003). Ubuntu: Reflections of a South African on our common humanity. Reflections, 4, 21-26. doi:10.1162/152417303322004175

Nussbaum, M. C. (2002). Patriotism and cosmopolitanism. In M. C.
Nussbaum, \& J. Cohen (Eds.), For the love of country (pp. 3-20). Boston, MA: Beacon Press.

Nzegwu, N. (1998). Chasing shadows: The misplaced search for matriarchy. Canadian Journal of African Studies, 32, 94-622.

doi: $10.2307 / 486330$

Peters, R. S. (1963). Education as initiation. Inaugural lecture delivered at the Institute of Education, University of London, London, 9 December.

Pretoria News (2012). Jail term for lesbian killers hailed. 1 February.

Ramose, M. B. (2006). The king as memory and symbol of African customary law. In M. O. Hinz, \& H. K. Patemann (Eds.), The shade of new leaves: Governance in traditional authority, a Southern Afrimcan perspective (pp. 351-374). Windhoek: Centre for Applied Social Sciences, University of Namibia.

Ramose, M. B. (2002). The philosophy of ubuntu and ubuntu as a philosophy. In P. H. Coetzee, \& A. P. J. Roux (Eds.), Philosophy from Africa: A text with readings (pp. 230-238). Cape Town: Oxford University Press.

Ramose, M. B. (1999). African Philosophy through Ubuntu. Harare: Mond Books Publishers.

Sartre, J. (2003). Being and nothingness: An essay on phenomenological ontology. London and New York: Routledge Classic.

Schwartz, B., \& Sharpe, K. (2012). Colleges should teach intellectual virtues. The Chronicle of Higher Education, 19 February.

Shanafelt, R. (1988). The heroic ideal in three Sotho novellas of labour migration. African Studies, 47, 47-61. doi:10.1080/00020188808707687

Shutte, A. (2001). Buntu: An ethic for the new South Africa. Pietermaritzburg: Cluster Publications.

Shutte, A. (1994). Philosophy for Africa. Rondebosch: UCT Press.

Sindane, J., \& Liebenberg, I. (2000). Reconstruction and the reciprocal other: The philosophy and practice of Ubuntu and democracy in African society. Politeia, 19, 31-46.

Sindane, J. (1994). Ubuntu and nation building. Pretoria: Ubuntu School of Philosophy.

Singer, P. (2002). Writings on an ethical life. London: Harper Collins Publishers.

Singer, P. (1997). How are we to live?: Ethics in an age of self-interest. New York: Oxford University Press.

Taylor, C. (1991). Cross-purposes: The liberal-communitarian debate. In N. Rosenblum (Ed.), Liberalism and the moral life (pp. 159-182). Cambridge, MA: Harvard University Press.

Teffo, L. J. (1994) The concept of Ubuntu as a cohesive moral value. Pretoria: Ubuntu School of Philosophy.

Wiredu, K. (1996). Cultural universals and particulars: An African perspective. Bloomington, IN: Indiana University Press.

Wiredu, K. (1992). The moral foundations of an African culture. In K. Wiredu, \& K. Gyekye (Eds.), Person and community: Ghanaian philosophical studies (Volume I, pp. 193-206). Washington DC: Council for Research in Values and Philosophy. 